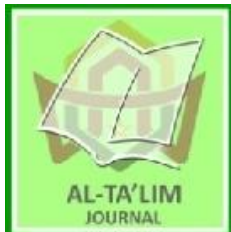

AL-TA'LIM JOURNAL, 27 (2), 2020, (166-178)

(Print ISSN 1410-7546 Online ISSN 2355-7893)

Available online at http://journal.tarbiyahiainib.ac.id/index.php/attalim

\title{
Management of Human Resources Development in Increasing the Quality of Islamic Education Institutions in Excellent Islamic Elementary School Bukittinggi City
}

Received: $12^{\text {th }}$ April 2020; Revised: $03^{\text {rd }}$ July 2020; Accepted: $30^{\text {th }}$ July 2020

Permalink/DOI: http://dx.doi.org/10.15548/it.v27i2.624

\section{Elvi Rahmi*)}

Institut Agama Islam Negeri

Tulungagung Jawa Timur, Indonesia

E-mail: elvi.rahmi17@gmail.com

\section{Achmad Patoni}

Institut Agama Islam Negeri

Tulungagung Jawa Timur, Indonesia

E-mail:_patoni_achmad@yahoo.co.id

\section{Sulistyorini}

Institut Agama Islam Negeri

Tulungagung Jawa Timur, Indonesia

E-mail: sulistyorini12@yahoo.com

\section{*) Corresponding Author}

\begin{abstract}
Human resources are the biggest strength in the management of Islamic educational institutions. The quality of human resources is crucial right now, because competence of human resources who have knowledge and skills will be able to cope environmental changes. Teachers and employees are the key of success in educational institutions. Good or bad performance of teachers and employees will support the competitiveness of schools. Based on this phenomenon, this research reveals the development of educators and education staff in enhancing competitiveness in the Excellent Islamic Elementary School in Bukittinggi City. This research uses descriptive qualitative. Located in Excellent Islamic Elementary School Bukittinggi City. The source of data in this study is the board of trustees, principals, teachers and employees. The techniques of data collection are participant observation, in-depth interviews and documentation. Later on the collected data is analyzed using data reduction techniques, data presentation, and conclusion. All data are approved by validity through a credibility test, transferability test, dependability test and conformability test. The results showed that the development of teachers and employees is done through 1) on the job training, that is, development that takes place during working hours takes place both formally and informally. 2) Off the job training, that is development that has done specifically outside of work. As for the development carried out: a) training in the form of quantum teaching training, workshops for making learning media and parenting seminars, b) rotation position, c) Religious Development, d) Teacher working groups $(\mathrm{KKG})$ and comparative studies. This development aims to improve the competencies of teachers and employees in the school environment so that they can improve the quality of Islamic educational institutions in accordance with the increasingly stringent times.
\end{abstract}

Keywords: Human resources; development management; quality of educational institutions.

How to Cite: Rahmi, E., Patoni, A., \& Sulistyorini, S. (2020). Management of Human Resources Development in Increasing the Quality of Islamic Education Institutions in Excellent Islamic Elementary School Bukittinggi City. Al-Ta lim Journal, 27(2). doi:https://doi.org/10.15548/jt.v27i2.624

\section{INTRODUCTION}

Islamic educational institutions are responsible for realizing the ideals, educating the nation's life in forming virtuous personalities who can prepare qualified human resources and be able to compete in global competition so as to create quality education in schools. (Mulyasa, 2007; Mundiri, 2016, 2017; Salleh, 2013). In this regard, effort to make Islamic educational institutions to survive and be able to compete 
in the era of globalization so that ultimately requires quality Islamic education institutions.

The main key in improving quality Islamic educational institutions lies in quality human resources, teaching staff and education staff as the key to the success of an educational institution. Good or bad behavior of teachers and employees will affect the image of the educational institution. Beside, of course it must be supported by quality management and interesting strategies, starting from the planning process to the maximum HR management system in order to be able to lift the image and competitiveness of schools in accordance with the increasingly stringent times (Becker \& Huselid, 2006; Brass, 2003; Daley, 2012; Soliman \& Spooner, 2000).

The quality of human resources becomes an important component on improving the quality of service in educational institutions, as follows: Quality dimensions found in human resources management are among the common components of the quality service and so in interaction with customer employees the value of employees looks for example: clothes, make up, abilities as well as codependents and skills. (Boxall, 2013; Gomez-Mejia et al., 2007; Haynes \& Fryer, 2000).

This shows that the quality of human resources is really needed in the modern era, of course it cannot be achieved in a short time, but it takes the stages of the process contained in the education program, so that, it can create quality human resources in accordance with social transformation quickly and good management. Human resources management has interested in scaling, motivation and in sustaining the function of human resources itself. Researchers in this field say that it is a trend toward improving the health of human resouces management. (Burma, 2014; Goswami, 2018; Mansoor et al., 2012; Schuler \& Jackson, 2008; Tariq et al., 2012). Human Resource management will determine the success of educational institutions, because with the good management of human resources it will have an effect on the progress of education. According to Reza is "Human Resources Management responsibility includes not only the presence of staff but also meeting the health, spiritual, and manage needs of creativity and staff skills" (Alami et al., 2015).

Human Resources is expected to be able to anticipate various developments that are currently and will occur, then take various actions to answer the challenges of globalization today, especially in improving HR performance so as to produce qualified teachers and employees to be able to produce superior students and ultimately be able to create quality and competitive advantages that are not owned by other institutions.

The quality of education is often interpreted as a characteristic of educational services that is in accordance with certain criteria to meet the satisfaction of users of educational services such as students, parents and other interested parties. On maintaining quality, it takes a long process so that quality control is needed that can oversee the process and all its supporting components. The quality of education is closely related to education graduates who have the appropriate abilities so that they can make a high contribution to Islamic educational institutions.

According to Sallis quality improvement is increasingly important for institutions to obtain better control by their own efforts. Good freedom must be adjusted with good accountability (Sallis, 2006). Educational institutions must demonstrate that they are able to provide quality education to students. Quality in education is something that distinguishes between success and failure. Quality is a major problem that will ensure the development of schools in achieving status amid increasingly fierce competition in the world of education (Ali \& Shastri, 2010; Sahney et al., 2004; Sharma, 2001; Thakkar et al., 2006).

Improving the quality of education becomes a commitment in every educational 
institution that must be manifested. One of the steps taken to realize this is by creating an excellence of human resources within the school environment. HR in the education institution is always colored by good or poor quality of the resulting education. Therefore, this HR issue occupies a strategic position in producing good quality education, especially in facing the current era of globalization.

The era of globalization conceptualizes the development of industry through the industrial revolution 4.0 which is the development of the previous industrial revolution. This 4.0 industrial revolution comes with new technology in form of machine tools, sensors; humans that are designed to be able to communicate interrelated with one another, able to use internet technology known as the "Internet of Things (IoT) (Maria et al., 2018). Mohammad Nasir, also said that the challenges of the 4.0 industry revolution must now respond quickly and responsively by all stakeholders so as to be able to increase the competitiveness of the Indonesian nation in the midst of competition. (Wulandari et al., 2019).

In the current era of globalization, the world has experienced increasingly complex changes that are determined by transnational processes. And in this process that there is a myriad of complexity, moreover a large amount of risk (Falk, 2000). Efforts in navigating such risks because globalization has driven expansion from the risk management industry on a global scale because many of these risks can be explicit understood as a consequence of globalization and global geopolitical behavior. Most of all these practices have focused on issues concerning economic and global globalization business (Zorub, 2014).

The era of globalization is certainly influential in the world of education that cannot be separated from the flow of information and technology development (Science and Technology). Therefore, to face these challenges, it is certainly necessary to have a global competitive advantage in order to increase capabilities and be able to gain knowledge of educational institutions that are able to compete with the challenges of the times.

Competitive advantage is needed by educational institutions as Dash said: : "A competitive advantage exist when a firm has a product or service that is perceived by its target market customers as better than that of its competitors"(Dash, 2013).

According to (Powell, 2001), these strengths are based on competitive advantage, which exists when there is an equivalence of distinctive competencies of a company, so the customer particular needs allow generating a competitive advantage. If associated with educational institutions, there is a competitive advantage when educational institutions have products and services that have differentiation from competitors (Vargas-Hernández, 2012).

Differentiation is an attempt by schools to create differences between competitors in terms of content, context and infrastructure, in order to provide the best value to service users (Kartajaya, 2007). It can be understood if the content is talking about what is offered (what to offer), then the context is talking about how to offer (how to offer), while the infrastructure shows about the difference to competitors based on the ability of technology and the ability of educational institutions to support the creation of content and context differentiation.

Education is the main means by which people reproduce and fight over their own identities. The existence of education will shape the personality, abilities and insight of the community. For this reason, a quality education is needed. (Ruth, 2018).

Quality is connected with the object itself, as the object cannot lose its quality, staying as it is. Thus, quality is a complex philosophical, economic and social category that could be cleared up through numerous definitions. (Georgieva \& Shakina, n.d.). Quality education is an indicator of the ability of institutions to provide education for the community in addition to being an instrument 
for the country's economic growth. it will have an effect on improving the quality and competitiveness of schools. (Azilah Anis, et al, 2014).

The quality and competitiveness of schools are needed especially in primary education institutions because primary schools are the main foundation of education and to compete in further education levels. Therefore certainly requires a very strong foundation in order to continue to survive and exist in the community and quality, and able to answer the challenges of increasingly stringent times. One of the schools that has high competitiveness in the Excellent Islamic Elementary School of Bukittinggi city.

With the vision of the school of "pious, achievement, character, healthy, creative and cultured environment", in the management of human resource development management carried out by Excellent Islamic Elementary School has special criteria in accordance with the guidelines that were previously designed. In recent years, the Excellent Islamic Elementary School in the learning process uses the qiro'aty method in learning the Qur'an. In addition, almost every semester provides guidance in the form of workshops, seminars and training in both the academic and religious fields. Academic fields such as curriculum training, and fostering teacher competencies through pedagogical competencies. While religious fields such as tahfiz, halaqoh Al-quran, English speaking are conducted once a week and the implementation of religious studies once a month. The training was carried out aimed for increasing teacher and employee competence in order to be competitive and have superior quality in the face of increasingly fierce competition in other elementary schools in the city of Bukittinggi.

Another advantage possessed by Islamic Elementary School Excellent is the existence of the program tahfiz and qira'ati, the program English language, computer learning programs, good academic and nonacademic achievements, have a magnificent learning building and enough space, sufficient teaching and educational staff, a prayer program in congregation, memorize juz'amma in accordance that has been determined by the local government of Bukittinggi the aim is that students who graduate from elementary school have memorized juz'amma. This school is an Adiwiyata school and achievers and won championships in various branches such as tahfiz al-quran, won medals in the whusu branch and received first place in the UN scores from 17 elementary schools in the Birugo Tigo Baleh District (ABTB) Bukittinggi City.

The explanation above explains that Excellent Islamic Elementary School has a competitive advantage strategy that is different from other schools. In addition, this site also focuses on students about tahfiz alquran, so it becomes a bargaining value to the community that eventually the community is interested in sending their children to the school. Some of the uniqueness described above, certainly can't be separated from the results of hard work owned by teachers and employees within the institution. Besides that, certainly supported by the implementation of good management that has been designed from school programs and implemented by the school principal as a milestone in the educational environment, so that eventually won many awards from various branches.

\section{METHOD}

This study uses a qualitative descriptive approach, namely research by describing an event or event that occurs in the field as it is, in this case relating to the principal's strategy in improving the quality of Islamic educational institutions is in Excellent Islamic Elementary School Bukittinggi City. Qualitative research is research that produces analytical procedures that do not use statistical analysis procedures or other quantification methods. (Moleong, 2011a). This research requires direct observation and involvement of researchers in dialogue with research sources. 
The presence of researchers is the one important element in qualitative research. Researchers are planners, implementers, data collectors and ultimately become pioneers of research. (Moleong, 2011b). Even in qualitative research the position of researchers as the main instrument (the key instrument). (Sugiono, 2008). Where researchers can assess the situation and make decisions on something from data collected or informed.

The source of data in research is the subject of where the data can be obtained. (Arikunto, 2010). The source of data in this study is the board of trustees, principals, teachers and employees who are in the Excellent Islamic Elementary School in Bukittinggi City. The number of informants is not limited by researchers because it uses the snowball technique (Snowball sampling) aimed at making data about HRM in improving the quality and competitiveness of schools more accurate.

The techniques of data collection are participant observation, in-depth interviews and documentation. These three data collection techniques aim to strengthen one another, none who was positioned as the main and complementary data. All three provide the information the researcher needs to answer the focus of the study.

The process of data analysis is carried out simultaneously with data collection through several stages ranging from the process of data collection, data reduction, data presentation and verification. After the data is collected, the data validity test is carried out, namely the credibility test, the transferability test, the dependability and the conformability test.(Nasution, 2003). This test is carried out so that the data produced can be trusted and scientifically justified.

\section{RESULT AND DISCUSSION}

Islamic educational institutions require unique human resources. As Suprayoga (2007). revealed, efforts to identify superior human resources are needed by Islamic education in the form of unique human resources. Therefore human resources in Islamic educational institutions need human resources who have high commitment and work loyalty to the institution. To create this, accurate strategies are needed in providing development to human resources in Islamic educational institutions.

With the development of the current era of globalization, human resource management don't only discuss humant resource planning, management planning support, training education, compensation and benefits as well as work relationships carried out in the environment of the organization. This activity aims to make the management carried to improve performance in order to improve competitiveness. (Thoo \& Kaliannan, 2013).

One indicator that makes Islamic educational institutions successful is seen from the performance of the human resources within it, in this case, it can be seen from the efforts that Islamic educational institutions must make and can be seen from the potential of existing human resources and supported by good management. In order to achieve this, Islamic educational institutions provide development for human resources, especially teachers and employees in an educational institution so that the principle of the right man on the right place can be achieved properly, besides that it will result in high productivity and quality of work so it creates quality and competitiveness for each educational institution. To express the existence of this HR can be seen in the letter at-Tiin verses 4-6 which read:

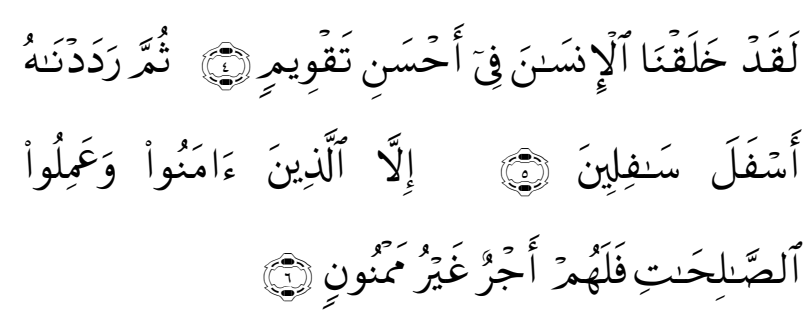

Meaning: Indeed, we have created man in the best form, and then we return him to the lowest of low people. Except for those who believe and do good 
deeds, then for them the reward is uninterrupted. (Q.S. At-tiin: 4-6).

The exposure of above version explains that every human being already has the potential since birth, humans are required to develop their potential optimally, and it is expected that the potential and strength possessed by every human being can be realized and applied in tangible form as devotion to God. This, if it is associated with Islamic educational institutions, it is hoped that schools will provide good development for every human resource available, especially teachers and employees.

Effective Management is an effort made by a leader to realize his beliefs about others, so of course he behaves in such a way as to look attractive and pleasant (Ghorbani \& Yekta, 2012). In today's competitive environment, the organizations are more concerned with the survival and development and their overall progress. To obtain this aim, the managers are seeking to optimally identify and utilize the resources and capital which are hard and expensive to be obtained. Therefore, the managers, who utilize the mentioned capital through the most effective and efficient way, will be successful in this regard. The major sources of each organization include the human, financial and technical resources, of which the human capital determines the direction and way of other capitals because it is the labor who can apply other resources through this abilities and planning (Manshadi et al., 2014).

Improving the quality of education must be carried out comprehensively which includes various components consisting of student, teachers, employees, education managers, facilities, infrastructure, and curriculum and school management. Education is a system that is mutually sustainable so that in this case school need collaboration between existing human resource personnel to improve the quality and competitiveness of school. According to some experts, it is stated that human resource management is the main key in creating good and productive performance development, because with the competence they have, it will create more value for an organization. For this reason, development must be given in accordance with their respective fields of expertise in order to create competitiveness in accordance with current developments. (Brito \& Oliveira, 2016).

And Iversen (2000), one way to achieve competitive advantage is seen from the differentiation of the organization so that these advantages can be used as strength to maintain its position in accordance with the times. (Varanavicius \& Navikaite, 2015). Training and development this is usually done to improve the ability of HR. HR activities are often enforced after conducting performance appraisals. In this way, training and development can help management to identify labor shortages, if any, in the company (Karikari et al., 2015).

This development refers to formal education, work experience, relationships, personality assessment and abilities that help employees prepare themselves in the future (Noe et al., 2017). This development is carried out as a form of school effort to improve the technical, theoretical, and personality abilities of teachers and employees in accordance with the needs of work or position through education and training. Education aims to improve the theoretical and personality possessed by teachers and employees, while training aims to improve the technical skills of implementing the work of teachers and employees.

According to Dassler (2013) that the techniques or methods of training teachers and employees can be done in two ways, namely on the job training and off the job training. In line with this, development program in Excellent Islamic Elementary School is carried out through two patterns or methods, namely, on the job training; this development is carried out during formal and informal working hours. Such as training, workshops, job rotation, religious activities, education, KKG, seminars and comparative studies. 


\section{Training}

Interpersonal skills have been considered a basic part of effective leadership. Leaders whose work so far controls, plans and oversees all organizational activities, will now provide motivation in creating quality human resources. One of them is certainly determined by the emotional intelligence possessed by the HR in that environment. According to the view of Golman (2005), the concept of emotional intelligence should be paid attention in leadership development strategies. A leader should have high emotional intelligence for success (Farahani et al., 2011). The existence of intelligence possessed by this leader will have an effect on the development program provided to the HR in the environment. HR development programs can be done in two ways: a) education and training (training), this development can be in the form of providing further education to employees or providing training to employees. b) Non-training career development, this development is like giving awards for employee achievements or promoting a higher position (Brewer \& Brewer, 2010; Madsen, 2004; Steyn \& Van Niekerk, 2002; Thirkell \& Ashman, 2014). The existence of a development program in the form of training can improve the competencies of teachers and employees.

Training conducted by Excellent Islamic Elementary School such as teacher quality development, teacher motivation training, training on how to create learning media, managing classes, quantum teaching training, K-13 development, teacher Olympiad and parenting so that it becomes differentiation for schools compared to other schools. The training conducted by the school aims to increase the knowledge of teachers and employees as the spearhead of school civilization, the qualities that are hard by teachers and employees can enhance the quality and competitiveness of schools. Therefore, schools must be able to provide development in accordance with the times.
This development program is carried out in two ways both formally and informally. This is in accordance with the opinion of Hasibuan (2000) that HR development is divided into two types namely formal development and non-formal development. Formal development relates to school programs, while in non-formal forms are activities that are attended by teachers and employees outside the school program. Workshop is one of the activities carried out by schools in providing development to teachers and employees, in increasing the scientific treasures they have. Besides, the Excellent Islamic Elementary School gave a seminar development. This activity can be a parenting seminar that refers to the atmosphere of teaching and learning activities that emphasize the warmth in providing learning to children (Ratna, 2007). The teacher as the second parent in school must be able to understand the attitude of the child, so that the teacher in the learning process in class can provide warmth, ultimately creating a conducive and pleasant learning atmosphere. The seminar is conducted by the teacher in order to increase knowledge about a particular topic and can open his inspiration in solving a problem, both in daily life and in the learning process.

Educational management includes an important aspect on achieving the learning process when faced with cognitive, emotional and psychomotor conditions. The quality of educational institutions is reflected in the quality of the learning process (Hakim, 2016). Therefore, the quality and success of learning must be organized in detail so that it can be measured and evaluated indicators of learning success in the school environment. Training provided by educational institutions to teachers and employees can improve their competence and insight and have an effect on improving the quality of schools.

\section{Job Rotation}

One of the most important parts of HRM is meeting satisfaction and motivating employees. In HRM theory, it is known as job 
enrichment and job redesign. Job enrichment is an effort to increase job satisfaction by adding one or several motivational factors to employee work activities (Stephen, 2003). Such as work rotation programs carried out through diverse positions in an educational institution.

Human resources within the institution are in dire need of public service motivation as a form of strengthening in carrying out work. This activity will have a large effect on the performance provided. Therefore the motivation of public services is very closely related to human resources in the work environment (Homberg \& Vogel, 2016). The rotation of the position given will give a new spirit to HR. This method will certainly provide an opportunity for employees to be able to add skills in the field they have just begun. This activity is in line with what is done by Excellent Islamic Elementary School where the school provides opportunities for teachers and employees to lead the school by periodically regenerating school management or the organizational structure of the institution changes every certain period. It means that schools do a job redesign that aims to increase the responsibilities and competencies of human resources within the school environment.

Job redesign is an activity in increasing employee job satisfaction in accordance with their position or area of expertise. The existence of this Job redesign will provide employee motivation in achieving the work performance that they do. This also happened in Excellent Islamic Elementary School where at first he became a teacher and then he was appointed as the principal, or who initially became an ordinary employee and then he was appointed as the head of administration and so on.

\section{Religious Activities}

Excellent Islamic Elementary School conducts religious activities in the form of religious studies, halaqoh al-qur'an in the form of tahfiz and also speaking English. This activity is used as a school tradition that aims for human resources within the school environment to have intellectual, moral and spiritual excellence. The conditions that have been developed at the Excellent Islamic Elementary School provide an overview of Islamic educational institutions based on science and religious values. So that this institution is able to attract the attention of people in this globalization era.

This development was carried out well because of the managerial competency of the principal in carrying out the task as a school manager to empower all available resources within the school environment to achieve school goals effectively and efficiently. The technical skills that are carried out are needed to coordinate and communicate with all parties so that all aspects of school management can be implemented (Asmendri et al., 2018).

This development was carried out to increase the capacity and religiosity insight of HR. Quantitatively the success of teachers and employees can be measured by their religious understanding. But the main focus is in terms of behavior and morality of teachers and employees in daily life as a vision of the educational institution. This religious activity aims to realize a religious Islamic education through the uswatun hasanah approach, skilled in worship and able to apply in everyday life. This activity aims to realize religious human resources that can serve as role models for students and the community.

\section{KKG}

This activity is carried out by schools to provide development for teachers in improving the learning process in the classroom. The KKG is carried out routinely twice a month at a school in the form of an intern-class KKG aimed at equalizing the perceptions of fellow class teachers in delivering learning material to students. Whereas the KKG between class levels brings speakers from outside or senior teachers to discuss certain material in order to increase the teacher's scientific insight. As Sabri 
(2015) opinion states that the teacher is a professional educator by carrying out his main task to direct, train, assess and evaluate students in formal education during childhood, basic education and secondary education.

Therefore, becoming a teacher is not easy because professionalism is needed in achieving goals to be in accordance with the development of science and technology. Teachers are required to be sensitive to the dynamics of development in society because this includes the progress of needs that are always changing from time to time. In achieving learning objectives teachers are required to use media and interesting learning methods, so as to create a pleasant learning atmosphere for students. So that this KKG can improve the knowledge of teachers in providing learning to students.

KKG can influence the learning objectives in class because one of the activities carried out using media in the learning process so that it can share experiences and delivery of material, the unclear material presented can also be helped by the presence of media as an intermediary or the complexity of the material presented to students can be simplified with the help of media. This agrees with Nasir (2019) who states that the learning process carried out now must be synchronized with learning through the following stages: a) determining the relative benefits, b) setting research objectives, c) design and integration strategies, d) preparing learning time, e) evaluating and improving the strategy of integration. Therefore, this KKG is a forum for teachers to share knowledge and sharpen their expertise to create a quality learning process. Besides that, teachers are also given a place to conduct comparative studies or educational visits conducted by schools that aim to open the horizons of teacher thinking so that the knowledge gained through this activity can be applied in schools. Educative visit has done schools like Malaysia, Jakarta, Pekanbaru and Padang.
The attention is given by Excellent Islamic Elementary School in carrying out organizational dynamics and various methods carried out in providing guidance to available resources in the school environment has a very good effect in improving the quality of competencies and performance possessed by HR who are in the school environment, eventually quality will be created schools to be superior and competitive schools with schools located in the of Bukittinggi City.

According to the opinion of development researchers found in Excellent Islamic Elementary School aims to: a) for new employees often do not understand about culture, rules or school regulations so that with the development can open their horizons in starting a job, b) training is a way to improve competence HR can be used as marketing by schools, in the sense that schools are able to spread da'wah to the community so that other Islamic schools emerge in Bukittinggi, c) the activities carried out by Islamic elementary school is excellent plus can increase the knowledge of teachers and employees so that they work more professionally. Excellent Islamic Elementary School always strives to enrich the scientific treasury, perceptions and awareness that teachers and employees must have towards the tasks and obligations they do especially in educating students and making those are human beings. The creation of a relationship between teachers, students and society based on the power of science and spirituality will make a strong Islamic $u k h w a h$.

Development programs carried out by Excellent Islamic Emanatory School such as workshops, training, seminars, KKG, and comparative studies. Some of these series of activities provide changes and positive impacts for schools, especially in terms of competencies, insights and qualities possessed by teachers and employees to improve school competitiveness, such as good student learning outcomes, teachers and students who have academic and non-academic achievements, schools a favorite in the community can be seen from the number of 
quotas that enter Excellent Islamic Elementary School each year compared to other schools.

In the line above, can be seen that the advantages possessed by Excellent Islamic Elementary School, namely: 1) the existence of tahfiz and qira'ati programs, 2) the existence of an English language program, 3) the existence of a computer learning program, 4) academic and non-academic achievements are very good, 5) has a magnificent building and sufficient space, 6) sufficient teaching and educational staff, 7) there is prayer activities in congregation, memorizing juz'amma that has been determined by the City Government of Bukittinggi, so that every student who completes elementary school is required to memorize juz'amma. The excellence of Excellent Islamic Elementary School provides competitiveness for other schools. For this reason, schools must be able to provide good development for teachers and employees in the school environment in a sustainable manner so that it has an effect on the progress of the school so that the school remains exceptional in the community. Excellent Islamic Elementary School has provided the best service to teachers and employees in the school environment in order to provide quality services to meet the needs and desires of the community, because the quality of this service is very important to be considered and maximized because this is the selling price and differentiation provided by the school in order to be able to survive and remain as a superior school and a choice for the community. This is proven that to this day the Excellent Islamic Elementary School is known for its environmentally friendly schools and excellent service is provided as proof to the community that this school is a favorite and superior school in the Bukittinggi city community.

\section{CONCLUSION RECOMMENDATION}

AND

Teacher and employee development in improving the quality of schools based on work programs that have been prepared by school management. With the development of the school so teachers and employees can develop all aspects of abilities in accordance with their respective main tasks. The form of development carried out by schools in the form of training or workshops and seminars, job rotation, religious activities, $\mathrm{KKG}$, and comparative studies. Based on this development, it can improve the competencies of teachers and employees so as to create the quality and competitiveness of schools in according to with the times of development.

The development provided by Islamic education institutions to teachers and employees has been going well in accordance with the vision and mission of the school. Hopefully this human resource development will be carried out by schools in a sustainable manner and provide development in accordance with the times and the needs of the community in order to be able to add insight and skills possessed by HR so that it can improve the quality of educational institutions to the maximum and have an advantage or differentiation with other schools in the surrounding environment.

\section{REFERENCES}

Alami, R., Sohaei, R., Berneti, A. K. M., Younesi, A., Farnia, M., \& Mirzajani, H. (2015). The Effectiveness of Human Resource Management on Improving the Performance of Education Staff. 6(5), 4.

Ali, M., \& Shastri, R. K. (2010). Implementation of total quality management in higher education. Asian Journal of Business Management, 2(1), 9-16.

Arikunto, Suharsimi. (2010). Research Procedure A Practical Approach. Rineka Cipta.

Asmendri, A., Marsidin, S., Rusdinal, R., \& Mukhaiyar, M. (2018). An Analysis of Managerial Competence of the Madrasah Principals in Islamic Senior 
High School in Tanah Datar. Al-Ta Lim Journal, 25(1), 56-70.

Azilah Anis, et al. (2014). Defining Quality Education In Higher Learning Institutions: Divergent Views of Stakeholders. International Journal Of Arts\&Sciences.

Becker, B. E., \& Huselid, M. A. (2006). Strategic human resources management: Where do we go from here? Journal of Management, 32(6), 898-925.

Boxall, P. (2013). Mutuality in the management of human resources: Assessing the quality of alignment in employment relationships. Human Resource Management Journal, 23(1), 3-17.

Brass, D. J. (2003). A social network perspective on human resources management. Networks in the Knowledge Economy, Oxford University Press, New York, NY, 283323.

Brewer, P. D., \& Brewer, K. L. (2010). Knowledge management, human resource management, and higher education: A theoretical model. Journal of Education for Business, 85(6), 330-335.

Brito, R., \& Oliveira, L. (2016). The Relationship Between Human Resource Management and Organizational Performance. Brazilian Business Review, 13(3), 90-110.

Burma, Z. A. (2014). Human resource management and its importance for today's organizations. International Journal of Education and Social Science, 1(2), 85-94.

Daley, D. M. (2012). Strategic human resources management. Public Personnel Management, 120-125.
Dash, D. A. K. (2013). Competitive advantage: its importance and impact on design of strategy. 2(12), 4.

E. Mulyasa. (2007). Manajemen Berbasis Sekolah. PT. Remaja Rosdakarya.

Edwar Sallis. (2006). Total Quality Management in Education; Manajemen Mutu Pendidikan. IRCiSoD.

Falk, R. (2000). The decline of citizenship in an era of globalization. Citizenship Studies, 4(1), 5-17.

Farahani, M., Taghadosi, M., \& Behboudi, M. (2011). An Exploration of the Relationship between Transformational Leadership and Organizational Commitment: The Moderating Effect of Emotional Intelligence: Case Study in Iran. International Business Research, 4(4),

Garry Dessler. (2013). Human Resource Management. International University.

Georgieva, N., \& Shakina, M. (n.d.). Education quality improvement via creating and introducing modern tools of interactive teaching. 22.

Ghorbani, M., \& Yekta, S. (2012). A Study of Relationship Between Transformational Leadership and Personnel Creativity in Higher Education Centers. 10.

Golman, D. (2005). Emotional intelligence: Emotional self knowledge, selfcontrolling, empathy and help others. Tehran: Roshd Publications.

Gomez-Mejia, L. R., Balkin, D. B., \& Cardy, R. L. (2007). Managing human resources. Pearson/Prentice Hall Upper Saddle River, NJ.

Goswami, A. (2018). Human resource management and its importance for today's organizations. Journal of Advances and Scholarly Researches in Allied Education, 15(3), 128-135. 
Hakim, Rosniati. (2016). Islamic Pre-School Management and Its Implications towards Students' Learning Quality Improvement. Al-Ta'lim Journal.

Haynes, P., \& Fryer, G. (2000). Human resources, service quality and performance: A case study. International Journal of Contemporary Hospitality Management, 12(4), 240-248.

Homberg, F., \& Vogel, R. (2016). Human resource management (HRM) and public service motivation (PSM): Where are we, and where do we go from here? International Journal of Manpower, 37(5), 746-763.

Imam Supayoga. (2007). Quo Vadis Madrasa, Ideas for Action \& Madrasah Development Solutions. Hikayat Publishing.

Karikari, A. F., Boateng, P. A., \& N. D. Ocansey, E. O. (2015). The Role of Human Resource Information System in the Process of Manpower Activities. American Journal of Industrial and Business Management, 05(06), 424.

Kartajaya, H. (2007). Hermawan Kartajaya on Differentiation. Mizan Pustaka.

Madsen, S. R. (2004). Academic service learning in human resource management education. Journal of Education for Business, 79(6), 328

Manshadi, M. D., Ebrahimi, F. P., \& Abdi, H. M. (2014). A study of the relationship between transformational leadership and organizational learning. 9.

Mansoor, N., Aslam, H. D., Javad, T., Ashraf, F., \& Shabbir, F. (2012). Exploring organizational citizenship behavior and its critical link to employee engagement for effectual human resource management in organizations. Mediterranean Journal of Social Sciences, 3(1), 567-567.
Maria, M., Shahbodin, F., \& Pee, N. C. (2018). Malaysian higher education system towards industry 4.0-current trends overview. AIP Conference Proceedings, 2016(1), 020081.

Megawati Ratna. (2007). Character Parenthing Space, Become Smart Parents To Awaken Children's Characters. Mizan Media Utama.

Melayu Hasibuan. (2000). Human Resource Management. PT. Rosda Karya.

Moleong, L. J. (2011). Metodologi Penelitian Kualitatif, cetakan XXIX. Bandung: PT. Remaja, Rosdakarya.

---. (2011). Prosedur Penelitian Kualitatif. Bandung: Remaja Rosdakarya.

Muhammad Nasir, et al. (2019). The Development of Teaching Materials on Integrated Science, Technology, and Religion to Improve College Students' Integrative Knowledge. . Al-Ta'lim Journal.

Mundiri, A. (2016). Strategi Lembaga Pendidikan Islam Dalam Membangun Branding Image. Pedagogik: Jurnal Pendidikan, 3(2).

Mundiri, A. (2017). Organizational Culture Base On Total Quality Management In Islamic Educational Institution. ADRI International Journal of Islamic Studies and Social Sciences, 1(1).

Noe, R. A., Hollenbeck, J. R., Gerhart, B., \& Wright, P. M. (2017). Human resource management: Gaining a competitive advantage. McGraw-Hill Education New York, NY.

Powell, T. C. (2001). Competitive advantage: Logical and philosophical considerations. Strategic Management Journal, 22(9), 875-888.

Ruth, D. (2018). Education as gift: Taking education out of the market and the market out of education. 27. 
S. Nasution. (2003). Qualitative Naturalistic Research Methods. Tarsito.

Sabri, Ahmad, Gusmaneli. (2015). The Using of Media in Learning Fiqh to the Islamic Education Department of Education and Teacher Faculty of IAIN Imam Bonjol Padang. Al-Ta'lim Journal.

Sahney, S., Banwet, D. K., \& Karunes, S. (2004). Conceptualizing total quality management in higher education. The TQM Magazine.

Salleh, M. S. (2013). Strategizing Islamic Education. International Journal of Education and Research, 1(6), 1-14.

Schuler, R. S., \& Jackson, S. E. (2008). Strategic human resource management. John Wiley \& Sons.

Sharma, R. C. (2001). Total quality management in education. Turkish Online Journal of Distance Education, 3(3).

Soliman, F., \& Spooner, K. (2000). Strategies for implementing knowledge management: Role of human resources management. Journal of Knowledge Management.

Stephen. P, Robbins. (2003). Character Parenthing Space, Become Smart Parents To Awaken Children's Characters. Gramedia.

Steyn, G. M., \& Van Niekerk, E. J. (2002). Human resource management in education. UNISA press.

Sugiono. (2008). Quantitative, Qualitative, and $R \& D$ Research Methods. Alfabeta.

Tariq, A., Aslam, H. D., Siddique, A., \& Tanveer, A. (2012). Work-Life Balance as a Best Practice Model of Human Resource Management: A Win-Win Situational Tool for the
Employees and Organizations. Mediterranean Journal of Social Sciences, 3(1), 577-577.

Thakkar, J., Deshmukh, S. G., \& Shastree, A. (2006). Total quality management (TQM) in self-financed technical institutions. Quality Assurance in Education.

Thirkell, E., \& Ashman, I. (2014). Lean towards learning: Connecting Lean Thinking and human resource management in UK higher education. The International Journal of Human Resource Management, 25(21), 2957.

Thoo, L., \& Kaliannan, M. (2013). International HR Assignment in Recruiting and Selecting: Challenges, Failures and Best Practices. International Journal of Human Resource Studies, 3(4), 143.

Varanavicius, V., \& Navikaite, A. (2015). Competitive advantage attainment via synergy in green offices. Journal of International Studies, 8, 11.

Vargas-Hernández, J. G. (2012). Sustainability as a strategy of responsible and competitive development. International Journal of Marketing and Management Research, 3(11 and12), 79-93.

Wulandari, F., Febriansyah, D., Salwa, S., \& Sulaiman, R. M. (2019). Kepemimpinan kepala sekolah di era revolusi industri 4.0 dalam meningkatkan akreditasi sekolah. Prosiding Seminar Nasional Program Pascasarjana Universitas PGRI Palembang, 12(01).

Zorub, D. (2014). Education \& the tumult of globalization: Considering political risk management for international education in an era of globalization. University of California, Santa Barbara. 